\title{
GENETICALLY MODIFIED PRODUCT USE AND TRADE REGULATION OF THE EUROPEAN UNION
}

\author{
Audrius GARGASAS ${ }^{1}$, INDRE் RIMKIENE் $\dot{2}^{2}$ \\ Aleksandras Stulginskis University (Lithuania)
}

\begin{abstract}
Can be accept a variety of viewpoints on genetically modified organism, as well as the products made using them. Therefore, the trade regulation rule base is different when considering different countries. It is noted that in particular the European Union member states formed a fairly tight trading policies of genetically modified organism and products. The article deals with analysis of the use of genetically modified products and trade regulation in the European Union. The object of research - the use of genetically modified products and trade regulation in the EU. The aim of the - of the EU's legal use of genetically modified products and their marketing of documents, it is structured. The study applied the following methods: a comparative analysis of legal documents as well as the synthesis, classification, modeling.

KEYWORDS: genetically modified organisms, genetically modified products, international regulation.
\end{abstract}

JEL CODES: Q17, Q18, D12

DOI: http://dx.doi.org/10.15181/rfds.v13i2.822

\section{Introduction}

The European Union's common commercial policy and regulatory instruments to choose reflects the views of its members on trade issues. Of course, this statement is not unambiguous, because of the sheer number of members and the differences in national approaches are difficult to reach a unified opinion on various issues. It must be emphasized that the Member States must comply with the general regulations adopted by the EU and to integrate them into the national legal framework.

The exclusive focus on trade, production and usage questions are given to genetically modified organisms (GMOs) and products made using them (GMP).

The object of research: the use of genetically modified products and trade regulation in the EU.

Objective of the study: analysis of the EU legal use of genetically modified products and their marketing documents, to submit the proposals of trade regulation.

1 Audrius Gargasas - associate professor, doctor of Aleksandras Stulginskis University, Faculty of Economy and Management, Institute of Business and rural development management

Scientific interests: management in agriculture, marketing of agricultural products

Address: Universiteto g. 10, LT-53361 Akademija, Kaunas distr.

E-mail: audrius.gargasas@asu.lt

Tel.: +370 37752278

2 Indre Rimkienè - assistant of Aleksandras Stulginskis University, Faculty of Economy and Management, Institute of Business and rural development management

Scientific interests: management in agriculture, marketing of agricultural products

Address: Universiteto g. 10, LT-53361 Akademija, Kaunas distr.

E-mail: indre.rimkiene@asu.lt

Tel.: +370 37752214 
Fulfillment of this goal will be to implement the following tasks of the article:

- disclosure of genetically modified crops and their production importance on the market;

- identify what kind of EU legal regulations regulating international trade of GMOs and GMPs;

- accomplish EU legal regulations governing international trade in GMOs and GMP analysis;

- submit proposals GMO and GMP trade adjustment.

Research methodology: a comparative analysis of legal documents, and synthesis, classification, modeling.

\section{Genetically modified plants and their products importance on the market}

The emergence of biotechnology has given rise significant research efforts directed to the market and welfare effects of the introduction of GM crops into the food system identification. The analysis by various scientists published works on this subject, in particular, need to release the potential economic benefits and risks in the event of the application of biotechnology in agriculture. It is important to identify the global green biotechnology effects attributable to sustainable development and global problems, and to provide for their potential impact in the future.

Economic-social impact, environmental impact studies, analysis of production, trade and welfare effects, many scientists used the gtaps or GTEM models. One study analyzed the impact on the global level (Brooks, Barfoot, 2008-2009; Clive, 2008; Moschini, 2001; Murphy et al., 2007), others focused on the impact of country-specific - K. Anderson C. Nielsen (2004) - Western Europe, A. Disdier, L. Fontagné (2008) - the third developing countries; A. Sonnino (2009) - Africa. Studies also varied according to the content analysis (sectoral studies, the total effect).

Existing studies can be broadly divided into several categories: one focuses on the direct economic benefits of simulations, while others use regression analysis and the general introduction of GM crops on the market effect. A. Plastina (2007) note that most studies have been focused on analysis of the consequences in developed countries and large developing countries with a direct influence on world prices (K. Anderson, L. A. Jackson [2006] in the U.S. and the EU; K. Giannakas, A. Plastina [2007] economic Policy for the uptake of GM crops in the U.S. and the EU). Researchers - A. Abdalla et al. (2003) on the first generation of GM products manufacturer targeting a particular focus on agronomic benefits (the new technology) and potential for productivity growth in developing countries.

According G. Moschini (2001), biotechnology applications in agriculture primarily influenced by increased profitability. Herbicide-tolerant and insect-resistant crops can reduce chemical use in agricultural production. G. Brooks and P. Barfoot (2008) studies claim that farmers growing GM crops, cash profits are higher. Depending on the crop diversity and local income leads to an increase in chemicals and fuel cost savings, and many examples of vintage gain. It was also found that higher profits are driven by other factors, such as the ability to produce herbicide-tolerant soybeans and corn in additional rows or alternately thereby saving farmland.

It should be noted that the cost savings to reduce the need to buy a new one every season seed at higher prices. In order to increase yield (technical effects) it is necessary to buy GM seeds, as well as special fertilizers and pesticides, and farmers' income (economic impact) increased by less than the yield (Sonnino, 2009). This can be explained by the fact that the biggest gains have patented seeds developers (with brand seed corporations in intellectual property), international biotechnology development company whose main goal - to increase profits, while the socio-economic implications for society, particularly in developing countries, may not always be useful. At the same time the company and the farmers supplying special fertilizer, herbicideresistant plants for fertilization, so there is a risk that the GMO development company can also enable the monopoly of genetically modified food in the market occur, without competition, to the use of farmers at extremely favorable conditions (Disdier, 2008).

Increased food supply (due to GM crop productivity increase) reduces the market price, which in turn reduces the farmers' standard of living, but a positive effect on consumers of cheaper and more abundant 
production market. A. Sonnino (2009) highlights the economic and other effects caused by the risks of GM crops, such as labor demand and workload changes in gender and K. Anderson (2006) highlights the inability of developing countries to compete in the international market trade of GM products because of different regulatory policies and trade restrictions. Legal aspects of protecting users will be discussed in the next section.

The emphasis on the benefits to consumers as an advantage over traditional food can be GMP distinguished nutrition and a more attractive appearance. The GMP advantages are especially important in developing countries, which suffer from lack of food or poor nutrition. On the potential of biotechnology to increase food supply and to deal effectively with the problems of hunger (Paulauskas, 2004). In addition, the cultivation of GM crops "freed" of arable land, reduced additional farmland development needs naikinat natural ecosystem. Also, reducing tillage intensity or dispense even without decreases the erosion process (Abdali, 2003).

A. Paulauskas (2009) note that the contribution of biotechnology to the alternative energy sector is growing, because they can be used to more efficient production of bioethanol and biodiesel. Advantage over other fuel production as to: the production of renewable energy, lower greenhouse gas emissions. Therefore, the development of biofuels could create many new jobs and open up new markets for agricultural products. It is also important for their application in the medical and pharmaceutical sectors, industrial processing and primary production (food and feed, as well as a renewable raw material, alternative energy). They can arise new problems related to health, aging, energy supply and global warming solutions.

Summarizing the various authors (Brooks, 2009; Clive, 2008; Sonnino, 2009) carried out the green biotech global impact analyzes, it can be said that green biotechnology has contributed to various aspects of sustainable development, which aims to meet human welfare in the present not to reduce the opportunities for future generations. The diagram (Fig. 1). depict the most important aspects of the positive effects revealed through sustainable development dimensions. Green biotechnology has led to many positive effects for the environment, economic development and social harmony. User group have a positive influence on a growing self-sufficiency - food security and increase affordability.

Summarizing J. Clive (2008), G. Brooks (2009) and other research studies, it can be said that the establishment and application of biotechnology in agriculture has so far contributed significantly to the global issues and sustainable development goals. On the other hand, the development of biotechnology has the potential of threats, including damage to human health, the environment and agriculture, since no technology can guarantee zero risk.

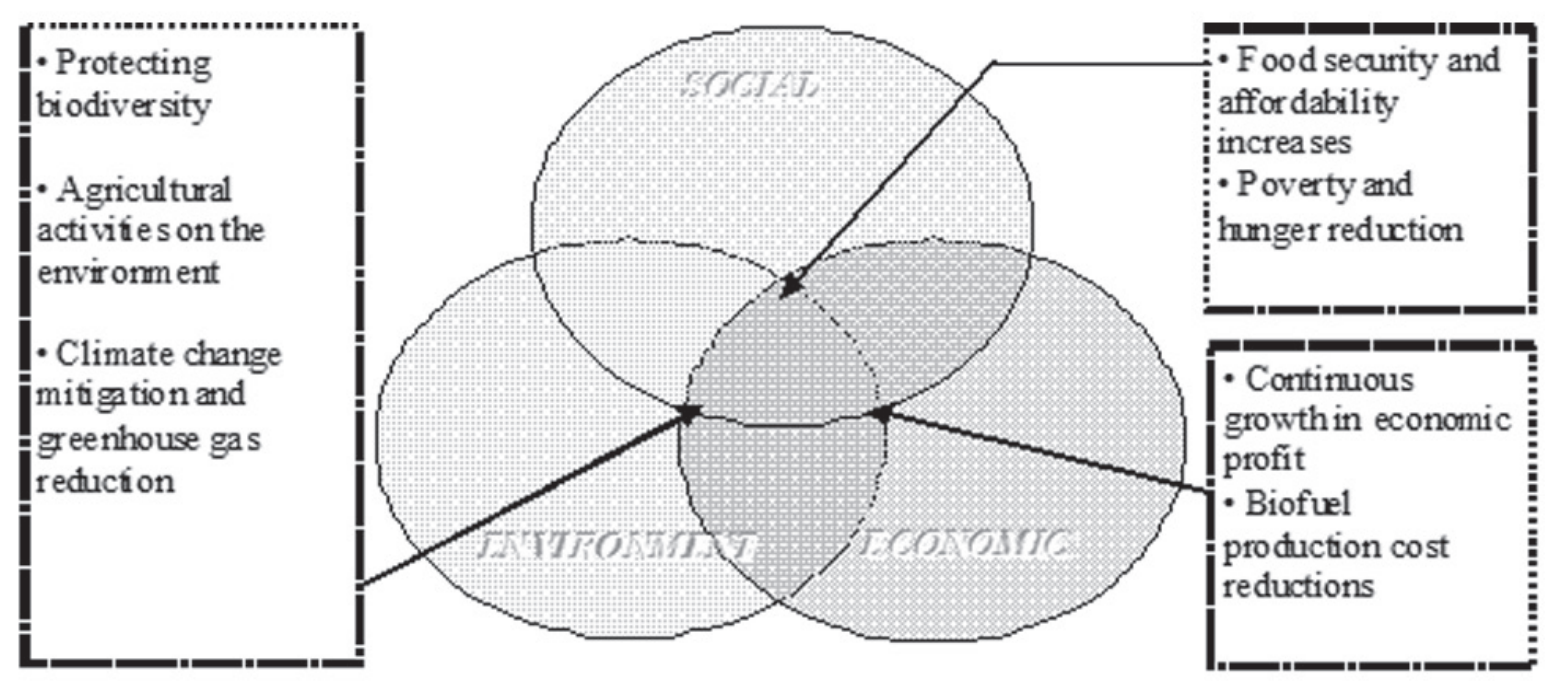

Figure 1. Green biotechnology's contribution to sustainable development

Source: developed by G. Brooks (2008), and J. Clive (2008). 
Biotechnology applications can have both positive and negative social, economic and environmental impacts as well as the direct benefits and costs of private producers. Despite the potential benefits of different countries, there are significant barriers to the successful application of biotechnology and use. In particular, green biotechnology products (especially food) consumption rates determined by social attitudes, acceptance of new technologies. Therefore, the use of biotechnology is dependent on the attitudes of society, which, for lack of information, not always rational. G. Moschini (2008), based on M. Rousu and J. Knight (2007) carried out market research on consumer opinions on GM products, emphasizes the flow of information and the nature of consumers' perceived personal changes the value of the products.

\section{Genetically modified products, usage and their trade regulation} in the European Union

EU member states have adopted a special regulatory regime in order to avoid potential health and environmental hazards caused by the input of biotechnology products. It is therefore enter into force in 1990, two new directives (90/219/EEC and 90/220/EEC). The first sets out the basic requirements for the creation and use of GMOs in closed areas - laboratories, greenhouses or corporate workshops. Second Directive sets out the basic requirements of GM crops, and trade in GMO products. However, soon ceased to comply with the directive of public desire to control the rapid onslaught of GM products in the EU market, so that the legal framework has been updated to the new directive and other legislation.

All GMO regulatory framework is based on the EU Cartagena Protocol on Biosafety, particularly on issues related to products imported into the EU and exports to third countries. Trade regulation system combined with the EU's international trade agreements (commitments) and WTO rules. As pointed A. Aleksynas (2006), part of the EU to adopt regulations to be approved individually by each country adopted laws. It is each member state has a certain degree of freedom for the preparation of GMOs rules and laws. But there is another part of the regulations that are not to be changed and take effect in all EU countries without exception. The main EU legislation to regulate the release of GMOs into the environment and placing on the market presented in Table 1.

Directive 2001/18/EC on the deliberate release of GMOs into the environment in the EU legislative framework on GMOs, which as the cornerstone of an integrated core Cartagena Biosafety Protocol. Under this Directive, the procedure considered GMOs which are discussed elsewhere in the legislation, the impact on the environment. Directive $\mathrm{A}$ and $\mathrm{D}$ are governed by the general requirements and the $\mathrm{C}$ and $\mathrm{B}-$ specific: B. adjustable experimental "test fields" procedures, Part C sets out the procedures to grant marketing authorizations across the EU. As pointed K. Virrankoski (2008), the directive introduced new GM crop rules substantially altered the previous Directives.

The main principle of the new provisions - genetically modified organism is a new phenomenon for which existing legislation is not enough. The EU regulatory system is more focused on the process rather than the product: this is how the product is produced is determined by the regulatory framework.

The major philosophical shift in Directive 2001/18/EC, as compared with the previous legislation - an obvious precautionary principle rather than similarity or substantial equivalence principles. The precautionary principle means that the evaluation of the GMO or EMS take into account the impact of any potential adverse effects, even when it might occur. However, this principle can't be a reason to depart from the basic principles of risk management - proportionality, consistency with the actions or lack of cost-benefit assessment and scientific developments. Food or feed, or for GMO food or feed products containing or produced from GMOs on the market addressed by Regulation (EC) No. 1829/2003 on genetically modified food and feed, which defines the authorization of such products, safety and labeling issues.

The analysis of international trade is important to emphasize to Regulation (EC) 1946/2003 on genetically modified organisms, the importance of cross-border movement, which applies to all of its food containing GMOs, GM food and GM feed. This Regulation supplements Directive 2001/18/EC defining the conditions for GM export commitments. 
Table 1. EU legislation concerning GMOs

\begin{tabular}{|l|l|}
\hline \multicolumn{1}{|c|}{ Title } & \multicolumn{1}{c|}{ Purpose / scope } \\
\hline $\begin{array}{l}\text { Council Directive 90/219/EEC } \\
\text { on the contained use of genetically } \\
\text { modified micro-organisms }\end{array}$ & $\begin{array}{l}\text { In order to protect human health and the environment, determined by the total } \\
\text { of genetically modified micro-organisms use tools }\end{array}$ \\
\hline $\begin{array}{l}\text { European Parliament and Council } \\
\text { Directive 2001/18/EC of genetically } \\
\text { modified organisms into the } \\
\text { environment and repealing Directive } \\
\text { 90/220/EEC }\end{array}$ & $\begin{array}{l}\text { On the basis of the precautionary principle, to harmonize national laws and } \\
\text { regulations and to protect human health and the environment when: } \\
\text { - Any other purposes than placing on the market within the Community } \\
\text { deliberate release into the environment of genetically modified organisms } \\
\text { - Community put on the market of genetically modified organisms as } \\
\text { products or in products }\end{array}$ \\
\hline $\begin{array}{l}\text { European Parliament and Council } \\
\text { Regulation (EC) No. 1829/2003 } \\
\text { on genetically modified food and } \\
\text { feed }\end{array}$ & $\begin{array}{l}\text { Apply for food use, food containing or consisting of GMOs, food produced } \\
\text { from GMOs or containing ingredients produced from GMOs, GMOs for feed } \\
\text { use, feed containing or consisting of GMOs; feed produced from GMOs }\end{array}$ \\
\hline $\begin{array}{l}\text { European Parliament and Council } \\
\text { Regulation (EC) 1946/2003 on } \\
\text { genetically modified transboundary } \\
\text { movements of organisms }\end{array}$ & $\begin{array}{l}\text { Applies to all GMOs that may have adverse effects on biodiversity conservation } \\
\text { and sustainable use, as well as taking into account the risks to human health, } \\
\text { the cross-border movement }\end{array}$ \\
\hline $\begin{array}{l}\text { European Parliament and Council } \\
\text { Regulation 1830/2003 on genetically } \\
\text { modified organisms and the } \\
\text { traceability of food and feed products } \\
\text { produced genetically modified } \\
\text { organisms and amending Directive } \\
\text { 2001/18/EC }\end{array}$ & $\begin{array}{l}\text { Forms the basis of the GMO consisting of or containing products produced } \\
\text { from GMOs in food and feed traceability to facilitate accurate labeling, } \\
\text { environmental impacts and, where applicable, health monitoring and } \\
\text { implementation of appropriate risk management measures, including, if } \\
\text { necessary, withdrawal of products }\end{array}$ \\
\hline
\end{tabular}
Source: developed by the author under the European Communities, 2009.

Another important aspect of the GM crop seeds and feed products produced labeling in accordance with Directive 98/95 EEC. Special label must be clearly stated that this is a genetically modified variety. In 2003 introduced the "Rules for new types of food" labeling threshold of 0.9 percent genetically modified material in food (Virrankoski, 2008). EU does not need to label only those foods (meat, eggs, milk) from animals that have been fed GMOs.

Labeling requirements for the mandatory implementation provides the user with information about the origin of the products and the opportunity to choose. On the other hand, strict labeling requirements that are different from the importing country, or potential trade partners (authorization incompatibilities), restricts imports. A. C. Disdier (2008) notes that even very slightly contaminated with GMO food is permitted in one country can lead to the introduction of the other party becomes illegal, what is prohibited on the wall or have already entered the market. This problem can only be solved at the international level on the basis of the Codex Alimentarius regulations.

From 1998 to 2003, the European Union has not been validated by a single new GMO product. The reason - the unofficial de facto moratorium on new GMO published a six member countries. During the five years, until the creation of a new use of the GMO regulation in the EU market was not admitted any new GM crops from or produced food or feed. In accordance with the precautionary principle, since 2003, entry into force of the new Directive and the new food, feed, labeling and other regulations as well as the creation of a special European Food Safety Authority (EFSA), the EU market failure in the new GMO products. Meanwhile, in the world of new GM products is rapidly increasing (Level, 2009).

European Union, the precautionary principle and the individual EU countries ban the end of 2003 end in GM de facto moratorium, prompting the United States, Canada and Argentina to start a debate and trade initiative with the World Trade Organization review of the EU regulatory framework. The parties argued that the period of 1998-2004 a policy of insurance was in fact just a protectionist measure, which did not rely on 
scientific data and concerns of its citizens health. Case for the moratorium ended in 2006, when the WTO working group decided that the EU violated the two cases of application of biotechnology legislation. Findings suggested that the EU violated the procedural obligations in implementing the Sanitary and Phytosanitary Agreement, the EU has been followed for four years in 2003 end a de facto moratorium on GMOs, and violations of fundamental terms of the contract due to unscientific GMO bans, previously approved by the competent authorities of the EU (Grinius, 2007).

Austria argues that the WTO is not taken into account in their decisions Biosafety Protocol because the applicants - the U.S., Canada and Argentina - it is not ratified. EU public has different opinion: in some countries (Spain, Portugal, England, Sweden, Finland, the Netherlands) in the GMO is viewed favorably, while others (Italy, Austria, Greece, France, Cyprus) are particularly damaging (Level, 2009). While the decision on the moratorium adopted by the highest authorities in the country, made a huge impact on public organizations themselves buyers: GM food shoppers have expressed reluctance to buy, so traders unprofitable production and import of these products. On the other hand, the European Union is banning the importation of such products in violation of free trade rules to being a member of the WTO must follow.

Due to the different countries approach to GM crops, which resulted in differences in their approval and entry control systems, formed a striking gap of authorized (approved) GM plants in different countries or regions. Annex 2 provides a list of authorized (and import) of GM soy, corn and canola in the various EU countries.

Based on GM food and feed register in accordance with Regulation (EC) 1829/2003 on the EU market for selected crops for food, legalize 16 varieties (11 corn, soybean 2, 3 rape) and 17 varieties of animal feed (12 corn, soybean 2, 3 canola). Comparing the EU with the main exporters of these crops (USA, Canada, Australia) shows that the EU-approved GM crops is considerably less, so this plant is the difference between authorization of import restrictions into the EU, the other parties do not have to carry all GM products and fodder grown legally and produced in their countries.

According A. C. Disdier (2008) analysis of the results of the moratorium on GM products, and other import restrictions, has had a negative impact on international trade. Moratorium, the main exporters annually lost 300 million. Dollars, and in 2003-2005 U.S. export losses are assessed at 1.6 billion dollars. However $\mathrm{K}$. Anderson (2006) argues that the new requirements may be more stringent restrictions on imports and more than a moratorium, as approved and authorized for the introduction of GM varieties subject to particularly strict labeling, traceability and liability law. On the other hand, GM labeling policy potentially creates a more efficient mechanism than the trade moratorium on granting priority of consumer choice to use non-GM food, but it is still import restriction especially in a developing country exporters - the necessary segregation and identity preservation systems. However, the adoption of the former site of the EU insurance will provide all consumers with a greater opportunity to choose what to use.

EU and other countries approved GM plant varieties showed that the EU market less than half admitted to the United States and Canada approved varieties. In particular, a significant difference apparent between Japan, where legalized 43 corn, canola and soybean varieties, while in the EU-17. Therefore, it becomes clear that the Europeans GMO resistance is the best example of how concerns about food safety and the natural environment can lead to protectionist policies. On the other hand, for more than a decade, revealed that the technology has been an important tool in order to improve agricultural productivity and to reduce the use of chemical pesticides. It is therefore adjustment, it seems justified in accordance with terms of the protection of human and environmental well-being.

A. C. Disdier (2008) consider that the EU protectionism is not based on concerns about the health of citizens, as it truly is a way to protect themselves and as excess food market from additional foreign production as an uneven playing field for competition.

D. Lygis (2009) highlights the persistent new GMO product validation process stops biotechnology in the EU and frustrate the objectives of the Lisbon strategy, as many education institutions to realize the possibilities of vision in their products out of business or emigrate. 


\section{Genetically modified products, usage and their trade regulation in Lithuania}

Lithuania belongs to the group of countries that is critical of GM crops in food needs and protect their markets by special laws. Home of genetically modified organisms, the Parliament adopted the law in 2001. It sets out the activities related to genetically modified organisms and products, area, as well as state management and regulation of these organisms and products of users' rights, duties and responsibilities. The law applies to all natural and legal persons who are related to the GMO and GMP deliberate release into the environment, use, marketing, testing and research work as well as the performance of the rest of this Law stipulates GMO and GMP-related activities in the territory of the Republic of Lithuania ${ }^{3}$.

Lithuanian legal framework relating to the GMO policy, developed and adjusted according to the international agreements and EU regulations. In 2001, Lithuania became a member of the WTO approved the accession documents - Ministry of obligations of the General Agreement on Tariffs and the WTO agreements as well as in 2003. Lithuanian Parliament ratified the Convention on Biological Diversity, the Cartagena Protocol on Biosafety.

Lithuania joined the EU, quality, food safety and other standards and certification procedures for interception of restricted some imports of goods from third countries in 2004. GM began to regulate the production and marketing of a horizontal line with the EU regulatory framework for genetically modified to develop international standards for labeling. After becoming a member of the EU's single market, the country can be grown all recognized by the EU and the common European agricultural plant varieties catalog includes a variety of plants and used in all EU allowed genetically modified products.

Although Lithuania GM crops not grown for commercial purposes, users can purchase imported products produced from GM plants or containing them. It is important that the products must be properly labeled and in accordance with legislative requirements. According to the European and national legislation, information for consumers about genetically modified organisms, the labels must be stated when their products contain more than 0.9 percent.

Based on the Ministry of Genetically Modified Organisms Act (2006), State Food and Veterinary Authority is responsible for placing on the market of GMOs for use in laboratories and their products, including veterinary products, commercial feed and food controls. Ministry of Agriculture is delegated to GM crops legal regulation. The GM seed crops and imported seeds are responsible for the control of the State Seed and Grain and the State Plant Protection Service.

Currently in Lithuanian market are 168 names of genetically modified food, the labeling indicates that it contains GMOs (Table 2).

It can be argued that all this time in GM foods Lithuanian market soy products or products from soybean, which consist mainly of vegetable oils. Other products (margarine, fat spreads, mayonnaise) must contain GM soya oil. Lithuania traded and sweets containing GM soya. GM product list, compared with all food types in the Lithuanian market is a very small part of it, but is available to every user. While the EU market, and allowed these types of products are intended for food production, as some GM corn, canola varieties, but in Lithuania foods containing them imported.

It should be noted that Lithuanian companies manufacture bread, confectionery, culinary products, as well as catering to a wide range of companies manufacture a variety of dishes. Genetically modified food products are sold in conjunction with conventional foods, but their labels must contain information showing that foods containing genetically modified organisms (State Food (...), 2009).

Therefore, an analysis of the provisions of the Republic of Lithuania GM trade and is the legal framework, it is clear that trade is strictly regulated by import bans when the market can not get products containing EU unapproved GM plants. Also create mandatory labeling requirements, risk, imports under investigation, and on the market of GM products list is kept Adjustment and publicly published. Run custom public opinion and knowledge on GMO research has shown that the citizens formed a negative attitude to the pro-

Republic of Lithuania Law on Genetically Modified Organisms (Žin., 2001, Nr. 56-1976; 2003, Nr. 34-1419; 2006, Nr. 77-2967). 
duction and the desire to further strengthen the GM products on the Lithuanian market. This indicates that in the near future, GM restriction on trade reduction is not likely and segregation of GM products in the market for traditional and organic products, the only deepen.

Table 2. Genetically modified foods market in Lithuania

\begin{tabular}{|l|l|l|l|l|l|}
\hline \multicolumn{1}{|c|}{ The type of a product } & \multicolumn{1}{|c|}{$\mathbf{2 0 0 7}$} & $\mathbf{2 0 0 9}$ & $\mathbf{2 0 1 0}$ & $\mathbf{2 0 1 1}$ & $\mathbf{2 0 1 2}$ \\
\hline $\begin{array}{l}\text { VEGETABLE OILS } \\
\text { (produced from genetically modified (GM) soya } \\
\text { beans or containing oil from genetically modified } \\
\text { soya beans) }\end{array}$ & 22 & 22 & 24 & 26 & 19 \\
\hline $\begin{array}{l}\text { MARGARINE, FAT SPREADS } \\
\text { (containing oil produced from GM soya beans) }\end{array}$ & 6 & 7 & 7 & 7 & 1 \\
\hline $\begin{array}{l}\text { DESSERTS } \\
\text { (containing GM soya products) }\end{array}$ & 8 & 10 & 31 & 43 & 47 \\
\hline $\begin{array}{l}\text { MAYONNAISE } \\
\text { (containing soybean oil, produced from GM soya } \\
\text { bean) }\end{array}$ & 2 & 3 & 1 & 1 & $?$ \\
\hline $\begin{array}{l}\text { FOOD ADDITIVES } \\
\text { (containing GM soya products) }\end{array}$ & - & 1 & 3 & - & - \\
\hline $\begin{array}{l}\text { TOASTED BREAD } \\
\text { (which was fried in soybean oil, produced from } \\
\text { GM soya bean) }\end{array}$ & - & 1 & 1 & 2 & 2 \\
\hline OTHER FOODS PRODUCTS & - & - & 96 & 97 & 99 \\
\hline TOTAL & 38 & 44 & 163 & 176 & 168 \\
\hline
\end{tabular}

Source: compiled by the authors after the data from the State Food and Veterinary Authority of the Republic of Lithuania, 2007, 2009, 2010, 2011, 2012.

Meanwhile, the country's aggregate demand for GM products affect not only their money but also their personal potential consumer attitudes, habits, expectations, and the perceived value of the product, ie, demand will depend on whether or not consumers disposed to pay a certain amount of money for products. Only when the current trends, people's attitudes and their determinants will be accepted conclusion or protectionist trade policies of the EU (to limited supply) are necessary and justified by the consumer provisions of the GMO and GMP use and trade regulation issues.

\section{Conclusions}

International, exclusively for the EU, genetically modified organisms, and the use of products and sales are regulated: EU directives and regulations, agriculture, the environment and genetically modified organisms regional policy (mainly for purpose - a complex regulation of the EU).

It was found that they concern in particular: 1) Council Directive 90/219/EEC on the contained use of genetically modified micro-organisms; 2) of the European Parliament and Council Directive 2001/18/EC on the deliberate release into the environment and repealing Directive 90/220 / EEC; 3) of the European Parliament and of the Council Regulation (EC) No. 1829/2003 on genetically modified food and feed; 4) of the European Parliament and of the Council Regulation (EC) 1946/2003 on genetically modified organisms cross-border movement of 5) The European Parliament and Council Regulation 1830/2003 on geneti- 
cally modified organisms and the traceability of food products and feed genetically modified organisms and amending Directive 2001/18/EC. Following the analysis of documents, identified the scope and objectives.

The first document of the Council Directive 90/219/EEC on the contained use of genetically modified micro-organisms in order to protect human health and the environment, establish common genetically modified micro-organisms use tools. "The European Parliament and Council Directive 2001/18/EC on the deliberate release into the environment and repealing Directive 90/220/EEC" On the basis of the precautionary principle, to harmonize national laws and regulations and to protect human health and the environment when: any other purposes than placing on the market within the Community deliberate release into the environment of genetically modified organisms; Community put on the market of genetically modified organisms as products or in products. "The European Parliament and Council Regulation" (EC) No. 1829/2003 on genetically modified food and feed "refers to food use, food containing or consisting of GMOs, food produced from GMOs or containing ingredients produced from GMOs, GMOs, which are used as feed, feed containing or consisting of GMOs; feed produced from GMOs". The European Parliament and Council Regulation (EC) $1946 / 2003$ on genetically modified organisms cross-border movement applies to all GMOs that may have adverse effects on biodiversity conservation and sustainable use, as well as taking into account the risks to human health, the cross-border movement. "The European Parliament and Council Regulation 1830/2003 on genetically modified organisms and the traceability of food and feed products produced genetically modified organisms and amending Directive 2001/18/EC" forms the basis of the GMO consisting of or containing products produced from GMOs in food and genetically modified organisms in order to facilitate accurate labeling, environmental impacts and, where applicable, health monitoring and appropriate risk management measures, including, if necessary, the withdrawal of market implementation.

Seemingly it appears that a critical mass of GMO trade and the use of the regulatory framework, but the European Union member countries have a quite different attitude in respect of the same GMO. Some countries are hostile to GMOs, it is proclaimed freedom from GMOs countries (Austria, Greece, Poland, Hungary), while others seem to rely on general legal principles regulating trade in GMOs. Therefore, consideration should be given an opportunity to the parties to define how strict trade regulation limits they are willing and able to set.

\section{References}

Abdalla, A. et al. (2003). Agricultural Biotechnology: Potential for Use in Developing Countries. ABARE eReport Canberra. Website: http://www.abareconomics.com/publications_html/economy/economy_03/er03_ag_biotech.pdf [2012 1124$]$.

Aleksynas, A. (2006). Daug triukšmo dèl genetiškai modifikuotų organizmų. Mano ūkis, Nr. 11, p. 34-37.

Anderson, K., Nielsen, C. (2004). Economic effects of agricultural biotechnology research in the presence of pricedistorting policies. Journal of Economic Integration, Nr. 19(2), p. 374-394.

Biologinès ịvairovès konvencijos Kartachenos biosaugos protokolas. Monrealis. (2000). Valstybès žinios, 2003 m., Nr. 98.

Brookes, G., Barfoot, P. (2009). GM Crops: Global Socio-economic and Environmental Impacts 1996-2007. P.G. Economics Ltd, Dorchester, UK. Website: http://www.agbioforum.org/v12n2/v12n2a04-brookes.pdf [2012 1118$]$.

Brookes, G., Barfoot, P. (2008). Global impact of biotech crops: Socio-economic and environmental effects, 19962006. AgBioForum, Vol. 11(1), p. 21-38. Website: http://www.agbioforum.org/v11n1/v11n1a03-brookes.htm [2012 11 22].

Clive, J. (2008). Global Status of Commercialized Biotech/GM Crops: 2008. The First Thirteen Years, 1996 to 2008. ISAAA Brief, No. 39. Website: http://croplife.intraspin.com/Biotech/papers/ID_372_james.pdf [2009 1122$].$

Codex Alimentarius Commission. (2009). Procedures and forthcoming activities]. Website: http://www.codexalimentarius.net/web/index_en.jsp [2012 1127$]$.

Disdier, A. C., Fontagne, L. (2008). Trade Impact of European Measures on GMOs Condemned by the WTO Panel. EAAE Congress 'People, Food and Environments: Global Trends and European Strategies'. Website: http://ageconsearch.umn.edu/bitstream/44392/2/153a.pdf [2012 11 29]. 
Friends of the Earth. (2006). Looking behind the US spin: WTO ruling does not prevent countries from restricting or banning GMOs. Website: <http://www.foeeurope.org/publications/2006/WTO_briefing.pdf> [2012 1128$]$.

Grinius, L. (2007). Genetiškai modifikuoti organizmai (GMO): ju poveikis aplinkai, žmoniu bei gyvūnu sveikatai ir ekologiškai švaraus maisto gamybai. Moderniosios biotechnologijos saugaus naudojimo ir vystymo perspektyvos Lietuvoje. Vilnius: Petro ofsetas.

Lietuvos Respublikos Genetiškai modifikuotų organizmų įstatymas. (2006). 2001 m. birželio 12 d., Nr. IX-375. Valstybés žinios, 2006-07-14, Nr. 77-2967.

Lygis, D. (2009). Europos Sajungos nuostatos dèl biotechnologijos vystymo ir GMO panaudojimo. Biotechnologijos saugaus naudojimo ir vystymo perspektyvos Lietuvoje. Mokslinės-praktinės konferencijos tezès. Vilnius: Inforastas.

LR Valstybinè maisto ir veterinarijos tarnyba. (2012). Patikslintas prekyboje esančiu maisto produktu, kuriu sudetyje yra genetiškai modifikuotu organizmu, sąrašas. Website: <http://www.vet.lt/lt/pages/view/?id=458> [2012 11 29].

Moschini, G. (2008). Biotechnology and the Development of Food Markets: Retrospect and Prospects. Working Paper 08-WP 477. Website: <http://www.card.iastate.edu/faculty/profiles/giancarlo_moschini/moschini_erae_2008.pdf> [2012 11 20].

Moschini, G. C. (2001). Economic Benefits and Costs of Biotechnology Innovations in Agriculture. Working Paper 01WP 264. Canadian Agri-Food Trade Research Network. Website: http://www.card.iastate.edu/publications/DBS/ PDFFiles/01wp264.pdf [2012 11 20].

Murphy, A. M. et al. (2007). Agricultural Biotechnology to 2030: "Steady Progress on Agricultural Biotechnology" Scenario. Website: http://www.oecd.org/dataoecd/12/57/40920458.pdf [2009 11 22].

Nuffield Council on Bioethics. (2004). The use of genetically modified crops in developing countries. Website: http:// www.efb-central.org/images/uploads/nuffieldcouncil.pdf [2012 11 21].

Paulauskas, A. (2009). Biotechnologijos rizikos vertinimas ir atsinaujinančių energijos išteklių plètra. Biotechnologijos saugaus naudojimo ir vystymo perspektyvos Lietuvoje. Mokslinės-praktinės konferencijos tezès. Vilnius: Inforastas.

Plastina, A., Giannakas, K. (2007). Market and welfare effects of GMO introduction in small open economies. AgBioForum, Vol. 10(2), p. 104-123. Website: http://www.agbioforum.org/v10n2/v10n2a05-giannakas.htm [2012 10 22].

Sonnino, A. et al. (2009). Socio-economic impacts of non-transgenic biotechnologies in developing countries. The case of plant micropropagation in Africa. FAO, Rome. Website: ftp://ftp.fao.org/docrep/fao/011/i0340e/i0340e.pdf [2012 11 13].

Tarptautinè sutartis dèl maisto ir žemès ūkio paskirties augalų genetinių išteklių. Preambulè. (2005). Valstybés žinios, Nr. 64-2267.

Virrankoski, K. (2008). Darbo dokumentas dèl biotechnologijų: Europos žemès ūkio perspektyvos ir uždaviniai Žemès ükio ir kaimo pletros komitetas. Website: www.europarl.europa.eu/activities/ committees/workingDocsCom. do?language $=$ LT\&body=AGRI [2012 10 22] .

World Trade Organization. (2009a). The WTO Agreement on the Application of Sanitary and Phytosanitary Measures (SPS Agreement). Website: http://www.wto.org/english/tratop_e/sps_e/spsagr_e.htm [2012 1021$]$.

World Trade Organization. (2009b). Standards and safety. Website: <http://www.wto.org/english/thewto_e/whatis_e/ tif_e/agrm4_e.htm>[2012 10 21].

\section{GENETIŠKAI MODIFIKUOTŲ PRODUKTŲ NAUDOJIMO IR JŲ PREKYBOS REGULIAVIMAS EUROPOS SĄJUNGOJE}

AUdRIUS GARGASAS, INDRE் RIMKIENĖ

Aleksandro Stulginskio universitetas

\section{Santrauka}

Yra ịvairių nuomonių tiek dèl genetiškai modifikuotų organizmų, tiek ir dèl produktų, pagamintų juos naudojant. Todèl ịvairiose šalyse skiriasi ir jų prekybos reguliavimo teisinè bazè. Pastebima, kad Europos Sajungos valstybių narių prekybos politika dèl genetiškai modifikuotų organizmų bei produktų yra gana griežta. 
Straipsnyje nagrinèjamas genetiškai modifikuotų produktų naudojimo ir jų prekybos reguliavimas Europos Sajungoje. Tyrimo objektas - genetiškai modifikuotų produktų naudojimo ir jų prekybos reguliavimas. Tyrimo tikslas - atlikus ES teisinių genetiškai modifikuotų produktų naudojimo ir jų prekybos dokumentų analizę, ją susisteminti. Atliekant tyrimą taikyti šie metodai: lyginamoji teisinių dokumentų analizè ir sintezė, klasifikavimas, modeliavimas. Straipsnyje pateikta siūlymų dèl genetiškai modifikuotų produktų naudojimo ir prekybos jais reguliavimo Europos Sajungoje.

PAGRINDINIAI ŽODŽIAI: genetiškai modifikuoti organizmai, genetiškai modifikuoti produktai, tarptautinis reguliavimas.

JEL KLASIFIKACIJA: Q17, Q18, D12 